WSRC-RP- 2001-00739

July 5, 2001

\title{
RISK-BASED RADIOACTIVE LIQUID EFFLUENT MONITORING REQUIREMENTS AT THE U.S. DEPARTMENT OF ENERGY'S SAVANNAH RIVER SITE
}

\author{
G. Timothy Jannik and Peter D. Fledderman \\ Westinghouse Savannah River Company \\ Savannah River Site \\ Aiken, SC 29808
}

\begin{abstract}
$\underline{\text { ABSTRACT }}$
For Department of Energy (DOE) facilities, clear regulatory guidance exists for structuring radiological air emissions monitoring programs. However, there are no parallel regulations for radiological liquid effluent monitoring programs. In order to bridge this gap and to technically justify liquid effluent monitoring decisions at DOE's Savannah River Site, a graded, risk-based approach has been established to determine the monitoring and sampling criteria to be applied at each liquid discharge point.
\end{abstract}


This document was prepared in conjunction with work accomplished under Contract No.

DE-AC09-96SR18500 with the U.S. Department of Energy.

\section{DISCLAIMER}

This report was prepared as an account of work sponsored by an agency of the United States Government. Neither the United States Government nor any agency thereof, nor any of their employees, makes any warranty, express or implied, or assumes any legal liability or responsibility for the accuracy, completeness, or usefulness of any information, apparatus, product or process disclosed, or represents that its use would not infringe privately owned rights. Reference herein to any specific commercial product, process or service by trade name, trademark, manufacturer, or otherwise does not necessarily constitute or imply its endorsement, recommendation, or favoring by the United States Government or any agency

thereof. The views and opinions of authors expressed herein do not necessarily state or reflect those of the United States Government or any agency thereof.

This report has been reproduced directly from the best available copy.

Available for sale to the public, in paper, from: U.S. Department of Commerce, National Technical Information Service, 5285 Port Royal Road, Springfield, VA 22161, phone: (800)

553-6847, fax: (703) 605-6900, email: orders@ntis.fedworld.gov online ordering: http://www.ntis.gov/ordering.htm

Available electronically at http://www.doe.gov/bridge

Available for a processing fee to U.S. Department of Energy and its contractors, in paper, from: U.S. Department of Energy, Office of Scientific and Technical Information, P.O. Box 62, Oak Ridge, TN 37831-0062, phone: (865 ) 576-8401, fax: (865) 576-5728, email: reports@ adonis.osti.gov 


\section{RISK-BASED RADIOACTIVE LIQUID EFFLUENT MONITORING REQUIREMENTS AT THE U.S. DEPARTMENT OF ENERGY'S SAVANNAH RIVER SITE}

\section{INTRODUCTION}

Although clear regulatory guidance exists for structuring a radiological air emmisions monitoring program at U.S. Department of Energy (DOE) sites, there is no parallel regulatory guidance for radiological liquid effluent monitoring activities.

Effluent monitoring requirements for radioactive airborne emissions from DOE facilities are specified in the National Emission Standards for Hazardous Air Pollutants (NESHAP) regulation of the U.S. Environmental Protection Agency (EPA) (EPA 1989). These requirements are incorporated in DOE (1991) and adopted by reference in DOE (1990).

However, for DOE facilities, there are no applicable federal regulations, DOE orders, or DOE guidance documents that specify at which levels continuous monitoring, continuous sampling, or periodic confirmatory measurements of radioactive liquid effluents must be made.

To bridge this gap and to technically justify and document liquid effluent monitoring decisions at the Savannah River Site (SRS), a graded, risk-based approach-in conjunction with limits on facility radionuclide inventories - has been established.

\section{DISCUSSION}

The graded, risk-based program requires that each SRS liquid effluent discharge point be categorized every year according to the maximum annual potential dose-determined at the point of discharge - by using the following parameters in the dose calculations:

- the highest annual average radionuclide concentrations - as determined during the previous 5 years of operations-measured in the actual liquid effluents released

- $\quad$ an ingestion rate of 2 liters per day (730 liters per year) of the untreated effluent

- the internal dose conversion factors from DOE (1988)

For new or previously unmonitored outfalls that potentially contain radioactive liquid effluents, this determination will be made by annualizing the data after at least 3 months of sampling and radioanalysis. This 3 month sampling period ensures that any residual radioactivity is accounted for. Weekly grab samples can be collected in lieu of continuous sampling if steady state process conditions can be verified.

The generic term "effluent monitoring" is defined in DOE Order 5400.5 as “... the collection and analysis of samples or measurements of liquid and gaseous effluents for purposes of characterizing and quantifying contaminants, assessing radiation exposures to members of the 
public, and demonstrating compliance with applicable standards." Therefore, when used in this document, "effluent monitoring" can refer to

- continuous direct measurement of radionuclides in the effluent stream

- $\quad$ sampling and analysis of the liquid waste prior to discharge as a batch release

- continuous sampling, followed by laboratory analyses, to determine the quantity of radionuclides present in the effluent stream

- periodic sampling, followed by laboratory analyses, to determine the quantity of radionuclides present in the effluent stream

\section{Radiological Liquid Effluent Source Categories}

Category I Sources: Category I sources have annual potential releases that, at the point of discharge and prior to dilution in the receiving stream, could cause a dose-via the water ingestion pathway (ingestion of $2 \mathrm{l} \mathrm{d}^{-1}$ of the effluent taken from the point of discharge) —of greater than $1.0 \mathrm{mSv} \mathrm{y}^{-1}\left(100 \mathrm{mrem} \mathrm{y}^{-1}\right)$. This is equivalent to exceeding the DOE Derived Concentration Guides (DCGs) at the point of discharge. As is the case with DOE DCG determinations, releases of tritium are exempted from the Category I source determinations. Category I sources are considered intolerable and must be treated by the best available technology, per DOE (1990).

Category II Sources: Category II sources have annual potential releases that, at the point of discharge and prior to dilution in the receiving stream, could cause a dose-via the water ingestion pathway - of between 0.04 and $1.0 \mathrm{mSv} \mathrm{y}^{-1}$ (4 and $100 \mathrm{mrem} \mathrm{y}^{-1}$ ). Category II sources may include discharge points that have potential doses greater than $1.0 \mathrm{mSv} \mathrm{y}^{-1}\left(100 \mathrm{mrem} \mathrm{y}^{-1}\right)$ per year because of tritium releases. Category II sources are required to have (on the process streams than contribute greater than $10 \%$ of the potential dose) 1) continuous monitoring (i.e., continuous online radiation detection instrumentation capable of producing an alarm signal and/or diverting the effluent stream if process alarm levels are exceeded) or 2) the capability to be batch released after sampling and radioanalyses. This type of source also requires continuous sampling, followed by laboratory radioanalyses, at the point of discharge to the receiving stream.

Category III Sources: Category III sources 1) have potential emissions that, at the point of discharge and prior to dilution in the receiving stream, could cause a dose-via the water ingestion pathway - of between 0.004 and $0.04 \mathrm{mSv} \mathrm{y}^{-1}\left(0.4\right.$ and $\left.4.0 \mathrm{mrem} \mathrm{y}^{-1}\right)$ and 2) have facilities-with radionuclide inventories that exceed the specified limits-emitting to them 9refer to radionuclide inventory limits section). Category III sources are required to have continuous sampling, followed by laboratory radioanalyses, at the point of discharge to the receiving stream.

Category IV Sources: Category IV sources 1) have potential emissions that, at the point of discharge and prior to dilution in the receiving stream, could cause a dose-via the water ingestion pathway - of between 0.004 and $0.04 \mathrm{mSv} \mathrm{y}^{-1}\left(0.4\right.$ and $\left.4.0 \mathrm{mrem} \mathrm{y}^{-1}\right)$ and 2) have 
facilities - with radionuclide inventories that are less than the specified limits—emitting to them. Category IV sources also include discharge points with potential emissions of less than $0.004 \mathrm{mSv} \mathrm{y}^{-1}\left(0.4 \mathrm{mrem} \mathrm{y}^{-1}\right)$ but have facilities - with radionuclide inventories that exceed the specified limits-emitting to them. Category IV sources are required to have periodic confirmatory measurements performed to ensure that emissions remain below $0.04 \mathrm{mSv} \mathrm{y}^{-1}(4.0$ mrem $\mathrm{y}^{-1}$ ).

Category V Sources: Category V sources have no potential for releasing radioactive liquid effluents, as determined by historical information and/or process knowledge. Category V sources also include discharge points that 1) have potential emissions that, at the point of discharge and prior to dilution in the receiving stream, could cause a dose-via the water ingestion pathway_of less than $0.004 \mathrm{mSv} \mathrm{y}^{-1}\left(0.4 \mathrm{mrem} \mathrm{y}^{-1}\right)$ and 2) have facilities — with facility radionuclide inventories that are less than the specified limits-emitting to them. Category $\mathrm{V}$ discharge points require no radiological liquid effluent monitoring.

\section{Risk Basis}

In Table 1, the liquid effluent source categories are shown with their associated annual ingestion-pathway-dose ranges and total-lifetime-stochastic-risk ranges. Categories I and II are based on the DOE (1990) primary dose standard of $1 \mathrm{mSv} \mathrm{y}^{-1}\left(100 \mathrm{mrem} \mathrm{y}^{-1}\right)$. They are conservatively applied at the point of discharge to a receiving stream, per DOE DCG requirements.

The International Commission on Radiological Protection (ICRP) factor for total, lifetime, stochastic risk (per effective dose) was used to determine the annual risk ranges shown in Table 1 (ICRP 1990).

The ICRP factor, which is $7.3 \times 10^{-5}$ per $\mathrm{mSv}\left(7.3 \times 10^{-7}\right.$ per mrem $)$, includes factors for

- fatal cancers of $5.0 \times 10^{-5}$ per $\mathrm{mSv}\left(5.0 \times 10^{-7}\right.$ per mrem $)$

- weighted nonfatal cancers of $1.0 \times 10^{-5}$ per $\mathrm{mSv}\left(1.0 \times 10^{-7}\right.$ per mrem $)$

- weighted severe hereditary effects of $1.3 \times 10^{-5}$ per $\mathrm{mSv}\left(1.3 \times 10^{-7}\right.$ per mrem $)$

It should be noted that risk factors, which are useful for risk management decisions, usually are not valid for assessment of risk from actual exposures. Actual risks that are at levels of natural background and below still are unknown.

Many of the established federal limits for radioactive releases correspond to limits on lifetime risks in the range of $10^{-4}$ to $10^{-6}$ (for example, DOE's $1.0 \mathrm{mSv} \mathrm{y}^{-1}\left(100 \mathrm{mrem} \mathrm{y}^{-1}\right)$ primary dose standard equates to a risk of $7.3 \times 10^{-5}$ ). Radiation exposures are reduced far below these limits by the application of As Low As Reasonably Achievable (ALARA) principles. This is accomplished by 1) the establishment of environmental standards, 2) limits on specific practices (i.e., DOE's and EPA's $0.1 \mathrm{mSv} \mathrm{y}^{-1}$ (10 $\left.\mathrm{mrem} \mathrm{y}^{-1}\right)$ standard for airborne releases), or 3) effluent source constraints. Lifetime risks below the range of $10^{-6}$ are so small that further reduction of 
risks using ALARA usually are not warranted and often are not possible. Therefore, exempting Category $\mathrm{V}$ sources from radiological liquid effluent monitoring requirements on a risk basis is justifiable.

Also, the less than $0.004 \mathrm{mSv}(0.4 \mathrm{mrem})$ dose range for Category IV and V sourceswhich is equivalent to radionuclide concentrations that are $0.4 \%$ of the DOE DCGs and $10 \%$ of the EPA drinking water dose standard-corresponds to liquid effluent radionuclide concentrations that approach the detection limits of most standard environmental radioanalytical procedures.

The low radionuclide concentrations (0.004 times the DOE DCGs) associated with the $0.004 \mathrm{mSv}$ (0.4 mrem) dose range further justify exempting Category $\mathrm{V}$ sources from radiological liquid effluent monitoring requirements. Also, employing 0.004 times the DCGs as a detection limit goal-which, for beta particle and photon emitters, is the same as the 40 CFR 141.25 analytical detection limit requirements-provides technical justification for the establishment of laboratory lower limits of detection.

\section{Facility Radionuclide Inventory Limits}

In addition to source category criteria levels, the graded, risk-based program establishes limits on facility radionuclide inventories above which some type of radiological liquid effluent monitoring must take place at a discharge point, regardless of how low the maximum potential drinking water dose is determined to be.

The established facility inventory limits are:

- $20 \mathrm{GBq}(0.5 \mathrm{Ci})$ of tritium

- $\quad 3.7 \mathrm{GBq}(0.1 \mathrm{Ci})$ of ${ }^{14} \mathrm{C}$

- $\quad 3.7 \mathrm{GBq}(0.1 \mathrm{Ci})$ of all other radionuclides combined

These limits are set conservatively at 10\% of the 10 CFR 20 (NRC 1977) annual limits on discharges to sanitary sewers. At SRS, these inventory amounts correspond to a maximally exposed individual dose-from all pathways and to the nearest offsite public receptor-of approximately $1.5 \times 10^{-3} \mathrm{mSv}\left(1.5 \times 10^{-1} \mathrm{mrem}\right)$, which is equivalent to a lifetime risk of about $1.0 \times 10^{-7}$. This dose assessment is based on the unlikely assumption that the entire allowable facility radionuclide inventory is discharged in one year and that a worst-case radionuclide accounts for the entire $3.7 \mathrm{GBq}(0.1 \mathrm{Ci})$ of all other radionuclides combined.

Considering the low potential doses and associated risks involved, exempting discharge points from more stringent radiological liquid effluent monitoring requirements on a facility radionuclide inventory risk basis is justifiable. In fact, on a risk basis, higher facility radionuclide inventory levels are justifiable at SRS. However, the factor-of-10 added conservatism ensures that-even using the highly unlikely assumption that entire facility radionuclide inventories are 
accidentally discharged at the same time-multiple exempted facility discharge points will not exceed the regulatory limits.

The facility radionuclide inventory limits are applicable to facilities that discharge to surface waters, as well as to facilities that discharge to sanitary sewers. The inventory limits are applicable to all physical forms of the radionuclides. However, calibration sources that are sealed and in a solid form are excluded from the facilities' inventory listing.

For a discharge point to be eligible for exemption from any liquid effluent monitoring requirements, it must be determined and documented that all facilities that discharge through that point are below the facility radionuclide inventory limits.

\section{Process for Determining Liquid Effluent Monitoring Requirements}

The flow chart process presented in Fig. 1 shows how the inventory limit is used in conjunction with the source categorizations to determine radioactive liquid effluent monitoring requirements at SRS.

\section{CONCLUSION}

The graded, risk-based program established for determining radioactive liquid effluent monitoring requirements at SRS is a conservative extension of liquid effluent requirements given in DOE (1990). Used in conjunction with each other, the source category criteria levels and facility radionuclide inventories allow for the best utilization of resources and provide consistent, technically justifiable determinations of radioactive liquid effluent monitoring requirements. To ensure that future changes in operations are accounted for, the potential dose from each source, as well as the facility radionuclide inventories, will be reassessed annually.

\section{REFERENCES}

International Commission on Radiological Protection. Risks associated with ionising radiations. Oxford: Pergamon Press; ICRP Publication 60, Ann. ICRP 22(1): 1991.

U.S. Department of Energy. General environmental protection program. Washington, DC: U.S. Government Printing Office; DOE Order 5400.1: 1988a.

U.S. Department of Energy. Internal dose conversion factors for calculation of dose to the public. Washington, DC: U.S. Government Printing Office; DOE/EH-0071: 1988b.

U.S. Department of Energy. Radiation protection of the public and environment. Washington, DC: U.S. Government Printing Office; DOE Order 5400.5: 1990.

U.S. Department of Energy. Environmental regulatory guide for radiological effluent monitoring and environmental surveillance. Washington, DC: U.S. Government Printing Office; DOE/EH-0173T: 1991. 
U.S. Environmental Protection Agency. Code of federal regulations. Washington, DC: U.S. Government Printing Office; 40 CFR 141: 1975.

U.S. Environmental Protection Agency. Code of federal regulations. Washington, DC: U.S. Government Printing Office; 40 CFR 61: 1989.

U.S Nuclear Regulatory Commission, Code of federal regulations. Washington, DC: U.S. Government Printing Office; 10 CFR 20: 1977. 
Table 1. Radioactive liquid effluent source categories

\begin{tabular}{cll}
\hline Category & \multicolumn{1}{c}{ Annual Dose Range } & Lifetime Risk From Annual Dose \\
\hline I & Greater than $1 \mathrm{mSv}(100 \mathrm{mrem})$ & Greater than $7.3 \times 10^{-5}$ \\
\hline II & $\begin{array}{l}\text { Greater than } 0.04 \mathrm{mSv}(4 \mathrm{mrem}) \\
\text { but less than } 1 \mathrm{mSv}(100 \mathrm{mrem})\end{array}$ & $\begin{array}{l}\text { Greater than } 2.9 \times 10^{-6} \\
\text { but less than } 7.3 \times 10^{-5}\end{array}$ \\
\hline III & $\begin{array}{l}\text { Greater than } 0.004 \mathrm{mSv}(0.4 \mathrm{mrem}) \\
\text { but less than } 0.04 \mathrm{mSv}(4 \mathrm{mrem})\end{array}$ & $\begin{array}{l}\text { Greater than } 2.9 \times 10^{-7} \\
\text { but less than } 2.9 \times 10^{-6}\end{array}$ \\
\hline IV & $\begin{array}{l}\text { Less than } 0.004 \mathrm{mSv}(0.4 \mathrm{mrem}) \\
\text { but inventory is over limits }\end{array}$ & Less than $2.9 \times 10^{-7}$ \\
\hline $\mathrm{V}$ & $\begin{array}{l}\text { Less than } 0.004 \mathrm{mSv}(0.4 \mathrm{mrem}) \\
\text { and inventory is under limits }\end{array}$ & \begin{tabular}{l} 
Less than $2.9 \times 10^{-7}$ \\
\hline
\end{tabular}
\end{tabular}


WSRC-RP-2001-00739

whe 50 1

Identified Liquid Effluent

Discharge Point
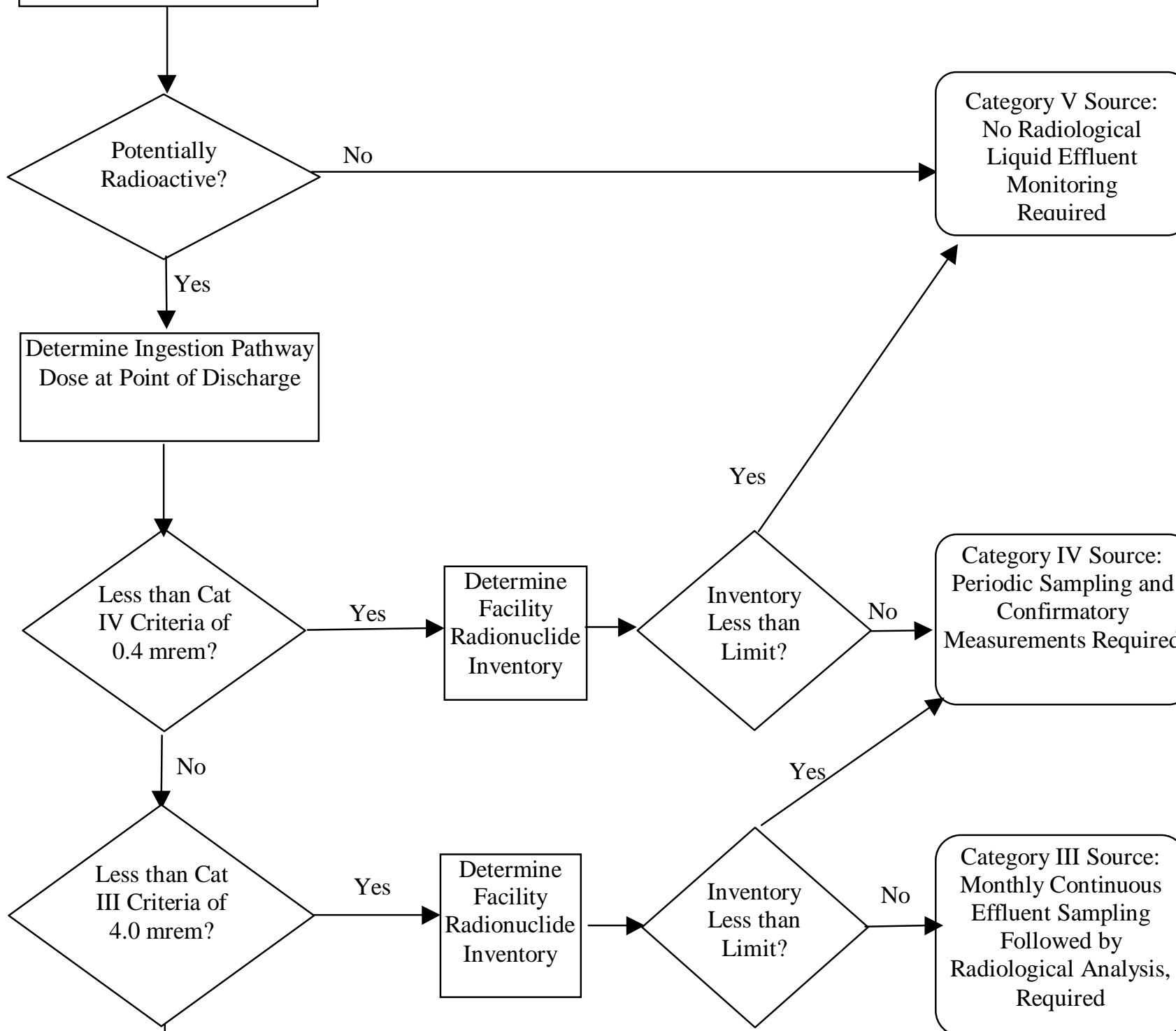

Category V Source:

No Radiological

Liquid Effluent

Monitoring

Required

Determine Ingestion Pathway

Dose at Point of Discharge

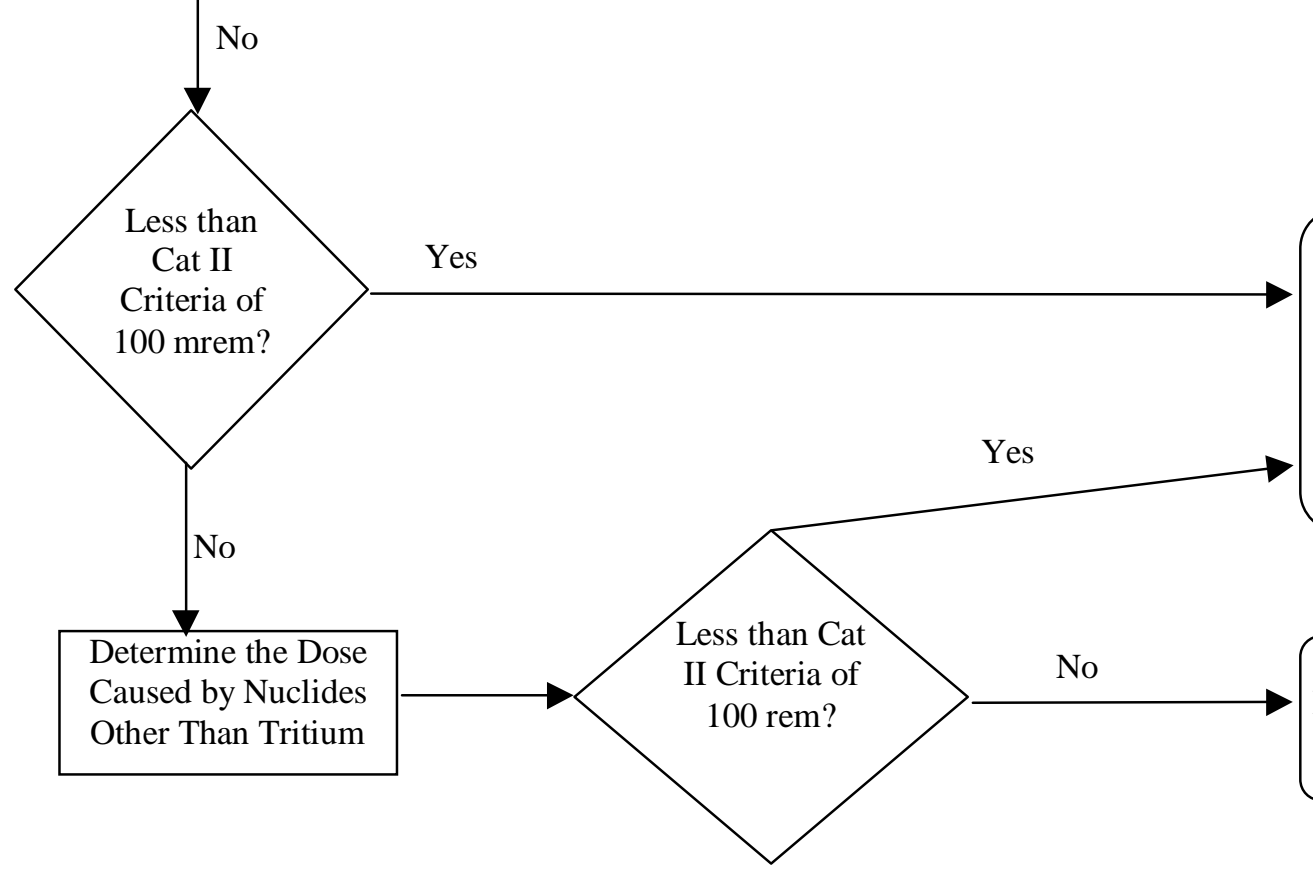

Category II Source:

Monthly Continuous

Radiological Effluent

Monitoring and

Sampling Analysis,

Required

Category I Source: Liquid Effluent Must be Treated by BAT, per DOE (1990)

Fig. 1. Flow chart process for determining radioactive liquid effluent monitoring requirements. 